\title{
Rancangan Eksperimen Acak
}

\author{
T. Dicky Hastjarjo ${ }^{1}$
}

Fakultas Psikologi Universitas Gadjah Mada

\section{Pengantar}

Rancangan eksperimen oleh McGuigan (1987) secara umum diartikan sebagai penerapan metode ilmiah yang diawali dengan merumuskan permasalahan, dilanjutkan dengan merumuskan hipotesis, menyeleksi partisipan, menempatkan partisipan ke kelompok eksperimen dan kontrol, menentukan variabel independen dan dependen, mengendalikan variabel luar yang relevan, melakukan analisa statistik, membuat generalisasi dan penjelasan hipotesis jika terkonfirmasi, serta diakhiri dengan memprediksi terhadap situasi baru lewat replikasi. Rumusan rancangan eksperimen versi McGuigan ini merupakan rumusan yang luas sebab halhal diatas merupakan penerapan tahapan seseorang didalam menyusun penelitian. Pengertian rancangan eksperimen secara lebih sempit dikemukakan oleh Kirk (1982) sebagai cara bagaimana sebuah eksperimen dilakukan dengan mengacu pada lima hal yang saling berkaitan, yakni; (a) perumusan hipotesis statistik, (b) penentuan variabel independen dan variabel pengganggu (nuisance variable), (c) spesifikasi jumlah unit eksperimen, (d) spesifikasi prosedur penempatan kondisi eksperimen ke subjek, dan (e) penentuan pengukuran variabel tergantung beserta analisis statistik. Sementara itu secara lebih sempit lagi Myers dan Hansen (2002) merumuskan rancangan eksperimen seba-

\footnotetext{
${ }^{1}$ Korespondensi mengenai artikel ini dapat melalui: dickyh@ugm.ac.id
}

gai struktur umum sebuah eksperimen, yang ditentukan oleh tiga aspek (a) jumlah variabel independen atau perlakuan, (b) jumlah variasi variabel independen atau kondisi perlakuan, dan (c) penggunaan subjek yang sama atau berbeda untuk masing-masing kondisi perlakuan.

Rancangan eksperimen telah dibahas baik di Program Sarjana maupun Program Magister Psikologi. Kuliah mengenai rancangan eksperimen pada Prodi Sarjana Psikologi Universitas Gadjah Mada berfokus pada rancangan eksperimen acak (randomized design) dengan mengacu pada buku Myers dan Hansen (2002), sedangkan untuk Program Studi Magister Psikologi (sering dijuluki Magister Sains) dan Magister Profesi Psikologi (sering dijuluki Magister Profesi) memfokuskan pada rancangan eksperimen-kuasi (quasi-experiment) atau rancangan bukan-acak (nonrandomized design). Buku eksperimen-kuasi warisan tradisi Donald Campbell yang ditulis Shadish, Cook, dan Campbell (2002) menjadi buku acuan. Rancangan subjek-tunggal (single-subject design) atau rancangan sampel kecil (small-sample design) menjadi materi kuliah penutup di Program Magister dengan menjadikan sumber acuan buku Barlow dan Hersen (1984) dan Cooper, Heron, dan Heward (1987). Mengkombinasikan pendapat Creswell (2009) yang membagi metode penelitian psikologi menjadi tiga serta sumber acuan diatas maka dapatlah dibuat bagan tentang metode penelitian seperti di Gambar 1. 


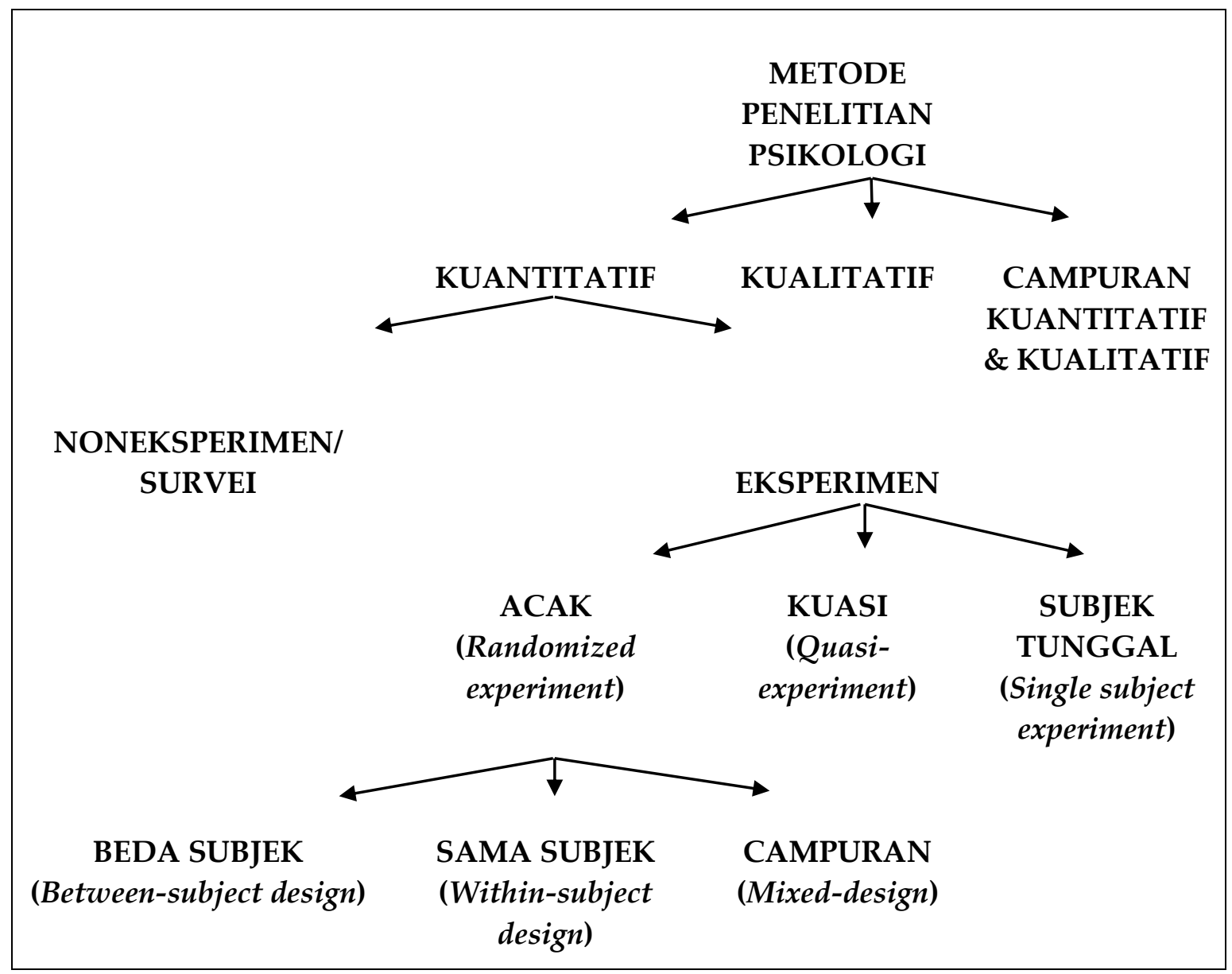

Gambar 1. Bagan metode penelitian psikologi

Gambar 1 sebenarnya belumlah komplit menggambarkan variasi rancangan eksperimen yang dikenal dalam bidang psikologi sebab gambar ini biasanya ditayangkan hanya untuk kebutuhan mahasiswa pengambil matakuliah Metode Penelitian Psikologi (MPP) dan matakuliah Metode Penelitian Kuantitatif (MPK) pada Kurikulum Psikologi 2011 (Penyempurnaan) prodi sarjana psikologi. Misalnya rancangan eksperimen-kuasi memiliki empat jenis rancangan serta masingmasing jenis masih dapat dirinci lagi sehingga total keseluruhan menjadi lebih dari 20 nama rancangan khusus. Demikian pula rancangan subjek tunggal masih dapat diklasifikasikan kedalam beberapa jenis rancangan. Tulisan ini hanya membatasi uraian mengenai rancangan acak (randomized design).

\section{Logika metode penelitian eksperimen}

Kerlinger dan Lee (2000) berpendapat bahwa meskipun metode eksperimen dengan metode noneksperimen berbeda namun kedua metode tersebut mempunyai tujuan dasar dan logika ilmiah yang sama. Tujuan dasar metode eksperimen dan non-eksperimen adalah mempelajari hubungan antara dua variabel atau lebih. Logika ilmiah kedua metode itu adalah menyediakan bukti empiris sehubungan dengan pernyataan kondisional yang berbentuk "Jika p maka q". Kerlinger (1986) memberi contoh untuk penelitian yang melibatkan dua variabel "Jika frustrasi (p) maka berperilaku agresif (q)" serta untuk penelitian dengan beberapa variabel "Jika inteligensi tinggi $\left(\mathrm{p}_{1}\right)$, kelas menengah $\left(\mathrm{p}_{2}\right)$, lelaki $\left(\mathrm{p}_{3}\right)$, dan frustrasi 
$\left(p_{4}\right)$ maka berperilaku agresif $(q)$ " atau contoh Kerlinger dan Lee (2000), “jika p 1 (frustrasi), akan berperilaku agresif (q) jika $\mathrm{p}_{2}$ (inteligensi tinggi), $\mathrm{p}_{3}$ (kelas menengah), dan lelaki ( $\left.\mathrm{p}_{4}\right)$.

Meskipun kedua metode penelitian mempunyai logika dasar yang sama, yaitu mencari hubungan antara variabel, namun metode eksperimen mencari hubungan yang lebih khusus: hubungan kausal (cause-effect, causal relationship, causality) antara sebuah variabel atau beberapa variabel dengan variabel lain. Hubungan yang diteliti oleh metode eksperimen dalam psikologi adalah hubungan kausal atau hubungan sebab dengan akibat/efek. Logika dasar metode eksperimen yang tergambar dalam pernyataan kondisional "Jika p maka q" menunjukkan bahwa $p$ adalah sebab dan $\mathrm{q}$ adalah efek/akibat. Istilah metodologisnya $\mathrm{p}$ adalah anteseden atau variabel independen yang dimanipulasi atau perlakuan, sedangkan $\mathrm{q}$ adalah variabel dependen atau dampak (outcome) dari perlakuan atau konsekuensi dari adanya manipulasi variabel independen. Sebuah eksperimen adalah sebuah penelitian sistematik dimana peneliti secara langsung membuat variasi sebuah atau beberapa faktor, membuat konstan faktorfaktor lain, dan mengamati akibat dari variasi tersebut (Goodwin, 2010). Variabel independen seringkali disebut faktor. Faktor yang secara sengaja dibuat variasinya oleh peneliti itu adalah variabel independen, variabel yang dibuat konstan adalah variabel luar (extraneous variable) sedangkan perilaku yang diukur sebagai akibat variasi variabel independen itu adalah variabel dependen. Jadi dapat disimpulkan bahwa sebuah eksperimen akan memunculkan variasi variabel independen, mengendalikan variabel luar, serta mengukur variabel dependen sebagai akibat adanya variasi variabel independen.
Metode noneksperimen kurang cocok dipakai menentukan hubungan kausal (Hastjarjo 2011, hlm. 5). Sebuah pernyataan relatif terkenal dalam pustaka penelitian berbunyi: "Korelasi tidak membuktikan hubungan kausal". Pernyataan ini dapat ditemukan dengan mudah dibuku pengantar psikologi pada bab metodologi (misal Gazzaniga, Heatherton \& Halpern, 2011; Passer \& Smith, 2007) dan terutama di buku metode eksperimen (misal Myers \& Hansen, 2002). Pernyataan demikian muncul oleh karena ketidakjelasan variabel mana yang terjadi lebih dahulu serta tidak tahu apakah ada penjelasan lain bagi efek yang terjadi. Shadish dkk. (2002) memberi contoh misalnya penghasilan dengan tingkat pendidikan orang berkorelasi. Bisa diajukan pertanyaan: apakah harus memiliki penghasilan tinggi dahulu sebelum mampu membiayai pendidikannya atau apakah perlu memiliki pendidikan yang baik dulu sebelum mendapatkan pekerjaan dengan penghasilan tinggi? Masing-masing kemungkinan bisa benar. Kelemahan lain studi korelasi adalah kurangnya peniadaan penjelasan alternatif untuk menerangkan hubungan antara dua variabel tadi, tingkat pendidikan dengan penghasilan. Hubungan kedua variabel mungkin bukan sebab-akibat namun dikarenakan oleh variabel ketiga (variabel pencemar) misalnya inteligensi. Jadi seandainya inteligensi yang tinggi menyebabkan kesuksesan dalam pendidikan maupun kesuksesan di pekerjaan, maka orang yang cerdas membuat ada korelasi antara tingkat pendidikan dengan besarnya penghasilan, Adanya korelasi antara tingkat pendidikan dengan besarnya penghasilan bukan karena pendidikan mempengaruhi penghasilan atau sebaliknya, melainkan keduanya dipengaruhi oleh inteligensi. Konsep problem variabel ketiga juga diuraikan oleh Passer dan Smith (2007, h. 43). Tugas sebuah eksperi- 
men adalah mengidentifikasikan variabel pencemar yang ada pada penelitian tertentu.

\section{Notasi rancangan}

Tidak semua buku eksperimen atau metode penelitian menyediakan notasi rancangan eksperimen (Kantowitz, Roediger \& Elmes, 2008; Keppel \& Wickens, 2004; McGuigan, 1997; Myers \& Hansen, 2002; Sani \& Todman, 2006; Solso, Johnson \& Beal, 1998), hanya buku warisan tradisi Campbell (Campbell \& Stanley, 1963; Cook \& Campbell, 1979; Shadish, Cook dan Campbell (2002) yang menyediakan notasi rancangan eksperimen. Tulisan ini mengikuti notasi Shadish dkk (2002) dengan memakai (a) huruf $X$ untuk menunjukkan perlakuan, (b) huruf O sebagai pengukuran variabel dependen. Tanda $\mathrm{O}_{1}$ menunjukkan pengukuran variabel dependen untuk pertamakali (biasanya disebut pretes/pengukuran praperlakuan meskipun tidak selalu begitu), dan $\mathrm{O}_{2}$ untuk pengukuran pasca perlakuan. (c) huruf $\mathrm{R}$ singkatan dari Random Assignment/penempatan secara acak subjek kedalam kelompok-kelompok eksperimen serta garis lurus yang memisahkan kelompok-kelompok eksperimen menggambarkan kelompok tersebut terbentuk secara acak, (d) Kelompok kontrol tanpa perlakuan tidak diberi huruf $X$. Tulisan ini juga mengikuti notasi Kirk (1982) mengenai huruf A sebagai perlakuan atau variabel independen dan $a_{1}$, a 2 serta a dengan nomer berikutnya sebagai kondisi perlakuan atau variasi variabel independen. Jadi sebagai rangkuman misalnya penelitian eksperimen mengenai pengaruh strategi belajar peta pemikiran (mind map) terhadap prestasi belajar matematika pascaperlakuan pada 20 siswa dikelompok peta pemikiran dan 20 siswa dikelompok kontrol yang terpilih secara acak, maka dapat digambarkan sebagai:

\begin{tabular}{ccc}
$\mathrm{R}$ & $\mathrm{X}$ & $\mathrm{O}_{1}$ \\
\hline $\mathrm{R}$ & & $\mathrm{O}_{2}$
\end{tabular}

Gambar 2. Rancangan dua kelompok hanya dengan pengukuran pascaperlakuan

Keterangan: $\mathrm{R}$ dan garis lurus pemisah antara kelompok eksperimen dan kontrol menunjukkan bahwa penempatan 40 subjek kedalam kelompok peta konsep (20 siswa) dan kelompok kontrol (20 siswa) dilakukan secara acak. Huruf $X$ menunjuk pada kondisi perlakuan peta pemikiran sedang kondisi kelompok kontrol adalah kelompok tanpa X. Pada kasus ini notasi $\mathrm{O}_{1}$ untuk menunjukkan pengukuran pascaperlakuan kelompok eksperimen satu dan $\mathrm{O}_{2}$ untuk menunjukkan pengukuran pascaperlakuan kelompok eksperimen kedua dalam rancangan yang sama juga. Hal ini dibuat agar peneliti dapat lebih mudah membedakan antara efek ketika ada perlakuan $\left(\mathrm{O}_{1}\right)$ dengan ketika tidak ada perlakuan $\left(\mathrm{O}_{2}\right)$.

Seandainya eksperimen diatas dielaborasi dengan meneliti mengenai pengaruh strategi belajar yang terdiri dari peta konsep (concept map) dan peta pemikiran (mind map) terhadap prestasi belajar matematika yang diukur baik praperlakuan dan pascaperlakuan pada 20 siswa dikelompok peta konsep dan 20 orang dikelompok peta pemikiran yang terpilih secara acak, maka dapat digambarkan sebagai:

$$
\begin{array}{llll}
\mathrm{R} & \mathrm{O}_{1} & \mathrm{X}_{1} & \mathrm{O}_{2} \\
\hline \mathrm{R} & \mathrm{O}_{1} & \mathrm{Xa}_{2} & \mathrm{O}_{2}
\end{array}
$$

Gambar 3. Rancangan dua kelompok dengan pengukuran praperlakuan dan pascaperlakuan 
Keterangan: Huruf $\mathrm{R}$ dan garis lurus pemisah antara dua kelompok eksperimen menunjukkan bahwa penempatan 40 subjek kedalam kelompok peta konsep (20 siswa) dan kelompok peta pemikiran (20 siswa) dilakukan secara acak. Huruf Xa1 menunjuk pada kondisi perlakuan peta konsep sedang $\mathrm{Xa}_{2}$ menunjuk pada kondisi perlakuan peta pemikiran. Huruf $\mathrm{O}_{1}$ menunjuk pada pengukuran prestasi belajar matematika praperlakuan dan $\mathrm{O}_{2}$ menunjuk pada pengukuran prestasi belajar matematika pascaperlakuan.

Seandainya eksperimen diatas dielaborasi lagi dengan membagi subjek secara acak menjadi tiga yaitu kelompok yaitu kelompok peta konsep (a1), kelompok peta pemikiran (a2) dan kelompok kontrol yang tidak diberi perlakuan apapun, maka rancangan eksperimen dapat digambarkan sebagai berikut:

\begin{tabular}{llll}
$\mathrm{R}$ & $\mathrm{O}_{1}$ & $\mathrm{X}_{1}$ & $\mathrm{O}_{2}$ \\
\hline $\mathrm{R}$ & $\mathrm{O}_{1}$ & $\mathrm{X}_{2}$ & $\mathrm{O}_{2}$ \\
\hline $\mathrm{R}$ & $\mathrm{O}_{1}$ & & $\mathrm{O}_{2}$
\end{tabular}

Gambar 4. Rancangan kelompok jamak dengan pengukuran praperlakuan dan pascaperlakuan

\section{Jenis rancangan}

Seperti telah disebutkan di awal tulisan ini, Myers dan Hansen (2002) merumuskan rancangan eksperimen sebagai struktur umum sebuah eksperimen, yang ditentukan oleh tiga aspek yaitu; (a) jumlah variabel independen atau perlakuan, (b) jumlah variasi independen variabel atau kondisi perlakuan, dan (c) penggunaan subjek yang sama atau berbeda untuk masing-masing kondisi perlakuan. Dengan mengacu pada ketiga aspek tadi rancangan eksperimen secara umum dapat diklasifikasikan kedalam; (a) rancangan beda-subjek (between-subjects designs), yakni rancangan eksperimen yang melibatkan kelompok orang yang berbeda dalam masing-masing kondisi perlakuan, (b) rancangan sama subjek (within-subjects designs), yakni rancangan yang melibatkan subjek yang sama dalam semua kondisi perlakuan, serta (c) rancangan campuran (mixed design) adalah sebuah rancangan eksperimen yang mengkombinasikan rancangan bedasubjek dengan rancangan sama subjek.

\section{Rancangan beda-subjek (between- subjects} designs)

Rancangan beda-subjek oleh Solso, Johnson, dan Beal (1998) maupun oleh McGuigan (1997) disebut sebagai rancangan beda-kelompok (between-groups design). Rancangan beda-subjek (between-subjects designs) adalah rancangan eksperimen yang melibatkan kelompok orang yang berbeda dalam masing-masing kondisi perlakuan dan dapat dibagi lagi menjadi; (a) rancangan eksperimen yang hanya meneliti pengaruh satu variabel independen atau perlakuan atau faktor, dan (b) rancangan eksperimen yang meneliti lebih dari satu variabel independen atau perlakuan atau faktor disebut sebagai rancangan faktorial (factorial design). Rancangan eksperimen yang hanya meneliti pengaruh satu variabel independen atas dasar jumlah kelompok kondisi perlakuan dapat digolongkan menjadi dua, yaitu; (a) rancangan dua kelompok dan (b) rancangan kelompok majemuk. Rancangan eksperimen dua kelompok berdasarkan cara pembentukannya dapat digolongkan menjadi dua yakni; (a) dua kelompok independen (two independent groups) yang terbentuk dengan cara penempatan subjek kedalam dua kondisi perlakuan secara acak (random assignment) dan (b) dua kelompok cocok-sebanding (two matched groups),yang melibatkan penempatan subjek kedalam 
dua kondisi perlakuan berdasar kecocokan dalam satu variabel lain tertentu yang diduga ikut berpengaruh terhadap variabel dependen.

Rancangan beda-subjek yang meneliti satu variabel independen dengan dua kelompok independen diuraikan berikut. Dua kelompok independen tersebut dapat terbentuk dari; (a) satu kelompok eksperimen yang mendapatkan perlakuan, dan satu kelompok kontrol yang tidak mendapatkan perlakuan atau (b) kedua kelompok mendapatkan variasi variabel independen berbeda. Sebuah eksperimen yang memiliki satu kelompok eksperimen dan satu kelompok kontrol contohnya adalah penelitian Utomo (2007) mengenai pengaruh emosi positif terhadap performansi memori jangka pendek. Variabel independen adalah emosi positif yang dimanipulasi dengan cara subjek diminta menggambarkan pengalaman yang membahagiakan atau menyenangkannya serta kemudian diminta membayangkan kembali pengalaman bahagia tersebut. Variabel dependennya adalah performansi memori jangka pendek yang diukur dengan tes rekognisi kata. Empatpuluh (40) subjek dibagi kedalam dua kelompok: kelompok eksperimen yang diberi perlakuan, dan kelompok kontrol yang tidak diberi perlakuan. Mengikuti notasi Shadish dkk (2002, hal. 258) rancangan ini disebut rancangan dasar dan digambarkan sebagai:

$\begin{array}{lll}R & X & O \\ R & & O\end{array}$

Gambar 5. Rancangan acak dasar (Shadish, dkk., 2002, hlm 258).

Keterangan: $\mathrm{R}$ = penempatan secara acak

$\mathrm{X}=$ perlakuan emosi positif

$\mathrm{O}=$ pengukuran performansi memori jangka-pendek pascaperlakuan
Notasi Shadish dkk. (2002) diatas tidak konsisten sebab pada saat menjelaskan notasi rancangan eksperimen-kuasi untuk rancangan dua kelompok nonekuivalen dan hanya dengan pengukuran pasca perlakuan (post test only design with nonequivalent group) dituliskan sebagai berikut;

\begin{tabular}{lrr}
$\mathrm{NR}$ & $\mathrm{X}$ & $\mathrm{O}_{1}$ \\
\hdashline $\mathrm{NR}$ & & $\mathrm{O}_{2}$
\end{tabular}

Gambar 6. Rancangan hanya pengukuran pasca perlakuan dengan kelompok non-ekuivalen (Shadish, dkk., 2002, hlm 116).

Keterangan: $X=$ perlakuan

$\mathrm{O}_{1}=$ pengukuran pascaperlakuan kelompok eksperimen

$\mathrm{O}_{2}=$ pengukuran pascaperlakuan kelompok kontrol

$\mathrm{NR}=$ nonrandomized assignment $=$ penugasan tidak acak.

Oleh karena itu seandainya mengikuti notasi yang diusulkan dalam tulisan ini maka eksperimen Utomo akan digambarkan sebagai berikut (bandingkan dengan Gambar 2);

\begin{tabular}{lll}
$\mathrm{R}$ & $\mathrm{X}$ & $\mathrm{O}_{1}$ \\
\hline $\mathrm{R}$ & & $\mathrm{O}_{2}$
\end{tabular}

Gambar7. Rancangan acak dua kelompok independen

Gambar 7 adalah rancangan eksperimen yang melibatkan kelompok eksperimen dan kelompok kontrol namun sebuah eksperimen yang melibatkan dua kelompok independen dapat terdiri dari kelompok eksperimen semua misalnya eksperimen yang meneliti pengaruh sistem latihan menari terhadap keterampilan menari. Di sebuah sanggar tari terdapat 20 siswa tari. Keduapuluh siswa tersebut dengan cara undian dibagi kedalam dua kelompok yaitu kelompok sistem tari 
perbagian dan kelompok sistem tari utuhmenyeluruh. Sistem latihan menari yang mengajarkan bagian per bagian diberikan kepada 10 siswa tari, sedangkan sistem latihan menari yang mengajarkan langsung sebuah tari secara utuh diberikan kepada 10 siswa tari lain. Penelitian seperti ini dilakukan oleh Poerbosari (1995) meskipun tidak persis. Rancangan eksperimen ini melibatkan dua kelompok eksperimen atau tepatnya dua kelompok kondisi perlakuan yang berbeda. Jika variabel independen atau perlakuan, yaitu sistem latihan menari diberi label A, maka kondisi perlakuan sistem menari perbagian dapat diberi label a1 dan kondisi perlakuan sistem latihan menari secara utuh dapat diberi label a2, sehingga sebaiknya rancangan ini dapat digambarkan berikut (Gambar 8).

\begin{tabular}{ccc}
$\mathrm{R}$ & $\mathrm{Xa}_{1}$ & $\mathrm{O}_{1}$ \\
\hline $\mathrm{R}$ & $\mathrm{Xa}_{2}$ & $\mathrm{O}_{2}$
\end{tabular}

Gambar 8. Rancangan acak dua kelompok independen

Keterangan:

$$
\begin{aligned}
\mathrm{R}= & \text { penempatan secara acak (random } \\
& \text { assignment) }
\end{aligned}
$$

Pembentukan dua kelompok juga dapat dilakukan dengan cara mencocokkan atau menyamakan kedua kelompok dalam satu variabel tertentu. Misalnya, kembali kecontoh penelitian mengenai pengaruh sistem latihan menari terhadap keterampilan menari dengan dua kelompok kondisi perlakuan. Keduapuluh siswa tari diukur inteligensinya terlebih dahulu, dan berdasarkan skor inteligensi mereka dibuatlah pasangan-pasangan (misal, siswa A dengan $K, I Q=110$; siswa $B$ dengan $L$, $\mathrm{IQ}=108$; siswa $\mathrm{C}$ dengan $\mathrm{M}, \mathrm{IQ}=105$ dan seterusnya). Setiap anggota sebuah pasangan (misal, A dan $\mathrm{K}$, atau $\mathrm{B}$ dan $\mathrm{L}$ atau $\mathrm{C}$ dan $\mathrm{M}$ dll.) kemudian dengan cara acak (misal diundi) ditempatkan kedalam kondisi perlakuan sistem tari perbagian atau sistem tari utuh-menyeluruh. Proses penyusunan dua kelompok atas dasar skor yang persis sama disebut sebagai pencocokkan persis (precision matching). Mendapatkan pasangan skor yang sama persis atau identik bukan hal mudah, sehingga dasar pencocokkan dapat dibuat dengan sebuah cara lain yaitu dengan cara menyusun kisaran skor. Subjek yang berada dalam kisaran skor yang sama dapat dijadikan pasangan. Kemudian setiap pasangan diundi siapa yang masuk ke kelompok sistem menari secara perbagian dan siapa yang masuk kedalam kelompok sistem menari secara utuh. Cara ini disebut range matching. Penulisan rancangan eksperimen yang melibatkan proses pencocokan sebuah variabel lain (matching) adalah sebagai berikut:

\begin{tabular}{ccc} 
MR & $\mathrm{Xa}_{1}$ & $\mathrm{O}_{1}$ \\
\hline $\mathrm{MR}$ & $\mathrm{Xa}_{2}$ & $\mathrm{O}_{2}$
\end{tabular}

Gambar 9. Rancangan berdasarkan matching Keterangan: $\mathrm{M}=$ Matching (Pencocokan berdasar satu variabel bebas lain) $\mathrm{R}=$ Penugasan secara acak.

Rancangan eksperimen yang meneliti satu variabel independen juga dapat dilakukan dengan memakai kelompok majemuk atau lebih dari dua kelompok. Misalnya, penelitian Faesal (1997) mengenai pengaruh jenis kertas brosur terhadap persepsi kualitas komputer. Jenis kertas yang dibuat untuk membuat brosur produk komputer sebagai variabel perlakuan dibagi menjadi tiga kondisi perlakuan, yakni kertas buku (HVS), kertas mengkilap, dan kertas daur ulang. Terdapat 90 mahasiswa yang secara acak dimasukkan kedalam ketiga kondisi perlakuan. Jika 
perlakuan (jenis kertas brosur) diberi label A, maka kertas buku (HVS) diberi label a1, kertas mengkilap diberi label a2, dan kertas daur ulang diberi label a3.

\begin{tabular}{ccc}
$\mathrm{R}$ & $\mathrm{Xa}_{1}$ & $\mathrm{O}_{1}$ \\
\hline $\mathrm{R}$ & $\mathrm{Xa}_{2}$ & $\mathrm{O}_{2}$ \\
\hline $\mathrm{R}$ & $\mathrm{Xa} 3$ & $\mathrm{O}_{3}$
\end{tabular}

Gambar 10. Rancangan acak kelompok jamak Ket: $\mathrm{R}$ = penempatan secara acak

Xa1 $=$ kelompok dengan kertas buku (HVS)

$\mathrm{Xa}_{2}=$ kelompok dengan kertas mengkilap

$\mathrm{Xa}_{3}=$ kelompok dengan kertas daur ulang

$\mathrm{O}=$ pengukuran persepsi kualitas komputer

Rancangan faktorial beda-subjek (between-subjects factorial designs) atau rancangan faktorial merupakan tipe terakhir rancangan beda-subjek. Rancangan faktorial adalah sebuah rancangan eksperimen yang melibatkan manipulasi lebih dari satu variabel independen (Myers \& Hansen, 2001). Masing-masing variabel independen atau perlakuan disebut sebagai faktor. Misalnya, Etsem, Walgito, Sugiyanto dan Priyosulistiyo (2008) menggunakan dua variabel independen yang dimanipulasi, yakni perlakuan pertama/ faktor pertama (1) jenis peta Anda Di Sini (peta ADS) dengan kondisi perlakuan: a) menganut prinsip Orientasi Arah Utara dan b) menganut arah subjek, serta perlakuan kedua/faktor kedua (2) rotasi penempatan peta ADS dengan sudut: (a) $0^{\circ}$, (b) $45^{\circ}$, (c) $90^{\circ}$, (d) $135^{\circ}$, (e) $180^{\circ}$, (f) $225^{\circ}$, (g) $270^{\circ}$, (h) $315^{\circ}$. Jadi dalam penelitian Etsem dkk. (2008) tadi ada dua)perlakuan atau faktor: perlakuan pertama (Faktor A) mempunyai dua kondisi perlakuan (a1 dan a2) sedangkan perlakuan kedua (Faktor B) mempunyai 8 (delapan) kondisi perlakuan ( $b_{1}, b_{2}, b_{3}, b_{4}, b_{5}, b_{6}, b_{7}$, dan $\left.b_{8}\right)$. Variabel dependennya adalah kecepatan pencarian jalan dan ketepatan pencarian jalan.
Penulisan rancangan faktorial eksperimen Etsem dkk (2008) diatas dapat berbentuk (a) metode pelabelan faktor: $2 \mathrm{x}$ 8 (jenis peta ADS $\mathrm{x}$ sudut rotasi) rancangan faktorial antara-subjek atau 2 (jenis peta ADS) × 8 (sudut rotasi) rancangan faktorial antara-subjek atau (b) metode faktor x level: $2 \times 8$ (Jenis Peta ADS: menganut prinsip OAU, menganut arah subjek x Sudut Rotasi: $0^{0}, 45^{\circ}, 90^{\circ}, 135^{\circ}$, $180^{\circ}, 225^{\circ}, 270^{\circ}, 315^{\circ}$ ) rancangan faktorial beda-subjek atau 2 (Jenis Peta ADS: menganut prinsip OAU, menganut arah subjek) x 8 (Sudut Rotasi: $0^{0}, 45^{\circ}, 90^{\circ}, 135^{\circ}$, $180^{\circ}, 225^{\circ}, 270^{\circ}, 315^{\circ}$ ) rancangan faktorial beda-subjek. Rancangan faktorial bedasubjek dapat digambarkan:

\begin{tabular}{|c|c|c|}
\hline $\mathrm{R}$ & $\mathrm{X}_{1} \mathrm{~b}_{1}$ & $\mathrm{O}_{1}$ \\
\hline $\mathrm{R}$ & $\mathrm{Xa}_{2} \mathrm{~b}_{1}$ & $\mathrm{O}_{2}$ \\
\hline $\mathrm{R}$ & $\mathrm{X}_{1} \mathrm{~b}_{2}$ & $\mathrm{O}_{3}$ \\
\hline $\mathrm{R}$ & $\mathrm{Xa}_{2} \mathrm{~b}_{2}$ & $\mathrm{O}_{4}$ \\
\hline $\mathrm{R}$ & $X a_{1} b_{3}$ & $\mathrm{O}_{5}$ \\
\hline $\mathrm{R}$ & $\mathrm{Xa}_{2} \mathrm{~b}_{3}$ & $\mathrm{O}_{6}$ \\
\hline $\mathrm{R}$ & $\mathrm{Xa}_{1} \mathrm{~b}_{4}$ & $\mathrm{O}_{7}$ \\
\hline $\mathrm{R}$ & $\mathrm{Xa}_{2} \mathrm{~b}_{4}$ & $\mathrm{O}_{8}$ \\
\hline $\mathrm{R}$ & $\mathrm{Xa}_{1} \mathrm{~b}_{5}$ & $\mathrm{O}_{9}$ \\
\hline $\mathrm{R}$ & $\mathrm{Xa}_{2} \mathrm{~b}_{5}$ & $\mathrm{O}_{10}$ \\
\hline $\mathrm{R}$ & $\mathrm{Xa}_{1} \mathrm{~b}_{6}$ & $\mathrm{O}_{11}$ \\
\hline $\mathrm{R}$ & $\mathrm{Xa}_{2} \mathrm{~b}_{6}$ & $\mathrm{O}_{12}$ \\
\hline $\mathrm{R}$ & $\mathrm{Xa}_{1} \mathrm{~b}_{7}$ & $\mathrm{O}_{13}$ \\
\hline $\mathrm{R}$ & $\mathrm{Xa}_{2} \mathrm{~b}_{7}$ & $\mathrm{O}_{14}$ \\
\hline $\mathrm{R}$ & $\mathrm{Xa}_{1} \mathrm{~b}_{8}$ & $\mathrm{O}_{15}$ \\
\hline $\mathrm{R}$ & $\mathrm{Xa}_{2} \mathrm{~b}_{8}$ & $\overline{\mathrm{O}_{16}}$ \\
\hline
\end{tabular}

\section{Gambar 11. Rancangan faktorial $2 \times 8$}

Rancangan faktorial dapat menghasilkan dua informasi penting, yaitu; (a) informasi mengenai efek utama, yaitu efek masing-masing variabel independen terhadap variabel dependen, dan (b) informasi 
mengenai efek interaksi. Jika terjadi interaksi maka efek satu variabel independen akan berubah tergantung pada level variabel independen lain. Misal, sebuah eksperimen pengaruh sistem latihan menari (sistem perbagian, a1 dan sistem keseluruhan, a2) dan tingkat kesulitan tari (mudah, $b_{1}$ dan sulit, $b_{2}$ ) terhadap keterampilan menari (skor 0-10). Pada gambar 12A, keterampilan menari dengan metode keseluruhan selalu lebih rendah dibandingkan dengan metode perbagian apapun taraf kesulitan tarinya. Demikian pula, keterampilan menari dengan tingkat kesulitan tari mudah selalu lebih tinggi daripada kalau tingkatnya sulit tidak peduli bagaimana sistem latihan menarinya. Sebaliknya, pada gambar 12B pengaruh sistem latihan menari akan tergantung tingkat kesulitan tarinya. Metode latihan per bagian akan menghasilkan keterampilan menari lebih rendah dibanding sistem latihan keseluruhan jika tingkat kesulitan menarinya mudah, namun keterampilan menari akan lebih baik dengan metode latihan perbagian daripada metode latihan keseluruhan jika taraf kesulitan tari sulit. Tidak bisa disimpulkan bahwa metode menari per bagian akan selalu lebih bagus menghasilkan keterampilan menari dibandingkan metode latihan keseluruhan. Jawabannya akan tergantung pada level variabel independen lain yaitu level variabel tingkat kesulitan tari.

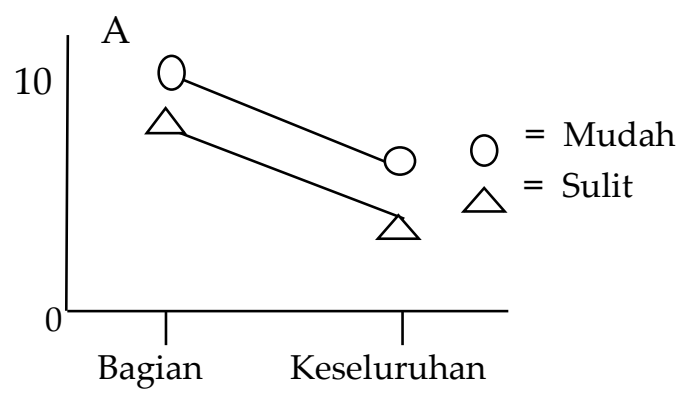

Gambar 12A. Tidak ada interaksi antara sistem latihan tari dengan tingkat kesulitan tari

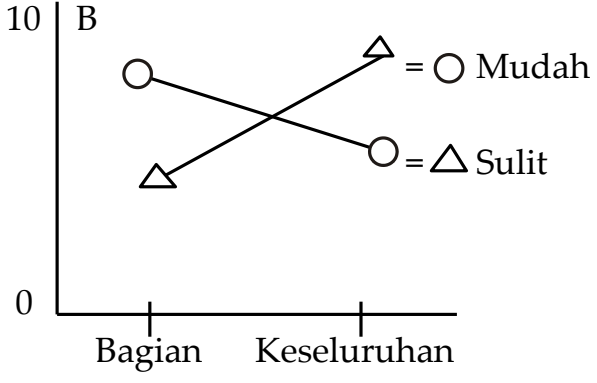

Gambar 12B. Terdapat interaksi antara sistem latihan tari dengan tingkat kesulitan tari

Rancangan sama subjek (within-subject design)

Rancangan sama-subjek merupakan rancangan yang melibatkan subjek yang sama dalam semua kondisi perlakuan. Dengan perkataan lain setiap subjek akan mendapatkan semua kondisi perlakuan atau semua level variabel independen yang ada dalam eksperimen. Dalam rancangan ini subjek mendapatkan lebih dari satu kondisi perlakuan dan diukur variabel dependennya sesudah mendapatkan setiap kondisi perlakuan sehingga disebut rancangan amatan ulangan (repeated measures design). Rancangan sama subjek dapat dilakukan dengan melibatkan satu variabel independen. Misalnya, penelitian Nadira (2010) mengenai pengaruh taraf kekonkritan kata terhadap performansi memori jangka pendek dengan mempertimbangkan tingkat efikasi diri memori. Variabel independennya (perlakuan) adalah taraf kekonkritan kata benda dengan dua kondisi perlakuan yaitu kata benda konkrit dan kata benda abstrak. Variabel dependennya adalah performansi memori yang diukur dengan recall bebas. Duapuluh lima (25) mahasiswa diminta menghafalkan sejumlah kata benda konkrit dan diminta mengingat kembali, lalu subjek yang sama diminta menghafalkan sejumlah kata abstrak dan juga diminta mengingat kembali. 
Dalam rancangan sama-subjek perlu diperhatikan metode counterbalancing. Misalnya, dalam penelitian Nadira (2010) tentang pengaruh taraf kekonkretan kata terhadap memori jangka-pendek diatas dengan dua kondisi perlakuan yaitu kata benda konkrit dan kata benda abstrak, maka dia melakukan counterbalancing urutan penyajian jenis kata benda yang harus diingat. Jumlah partisipan eksperimen adalah 25 mahasiswa. Kepada 12 mahasiswa Nadira menyajikan 15 kata benda konkrit selama 30 detik dengan durasi 2 detik per kata ( $\left.\mathrm{Xa}_{1}\right)$, lalu mahasiswa diminta merecall kata-kata tadi, disusul oleh penyajian 15 kata abstrak selama 30 detik dengan durasi 2 detik per kata $\left(\mathrm{Xa}_{2}\right)$ dan mahasiswa diminta merecall juga. Kepada 13 mahasiswa lainnya, urutan penyajian dibalik: penyajian 15 kata abstrak $\left(\mathrm{Xa}_{2}\right)$, tes recall dilakukan, penyajian 15 kata benda konkrit (Xa1), tes recall dilakukan. Secara umum ke 25 mahasiswa tadi mendapatkan penyajian 30 kata benda (15 kata benda konkrit dan 15 kata benda abstrak).

Penelitian dengan rancangan samasubjek yang dilakukan Nadira untuk ke 25 subjek dapat digambarkan seperti berikut:

$$
\mathrm{R} \mathrm{Xa}_{1} \mathrm{O}_{1} \mathrm{Xa}_{2} \mathrm{O}_{2} \quad \text { (untuk ke } 25 \text { subjek) }
$$

sedangkan sesudah dilakukan metode counterbalancing rancangan akan menjadi:

\begin{tabular}{lllll}
$\mathrm{RXa} 1$ & $\mathrm{O}_{1}$ & $\mathrm{Xa}_{2}$ & $\mathrm{O}_{2}$ & (untuk 12 subjek) \\
\hline $\mathrm{R} \mathrm{Xa} 2$ & $\mathrm{O}_{1}$ & $\mathrm{Xa}_{1}$ & $\mathrm{O}_{2}$ & (untuk 13 subjek)
\end{tabular}

Gambar 13. Rancangan sama-subjek dengan counterbalancing

Sebuah contoh lain rancangan samasubjek dengan melibatkan metode counterbalancing dilakukan Hastjarjo (2004) yang meneliti pengaruh skema penalaran pragmatis terhadap penalaran deduktif mahasiswa. Skema penalaran pragmatis adalah serangkaian aturan abstrak yang terkait dengan ranah tertentu untuk memecahkan problem hidup sehari-hari. Skema penalaran pragmatis pada penelitian terdahulu dibagi menjadi skema perizinan, skema kausal dan skema obligasi. Hastjarjo (2004) hanya menggunakan skema perijinan dan kausal dibandingkan dengan skema arbitrer sebab mengikuti penelitian Thompson (1995), skema perijinan akan lebih mudah dinalar daripada skema kausal dan arbitrer. Hastjarjo menggunakan counter balancing sebab ada tiga kelompok urutan penyajian kondisi perlakuan: A (arbitrer, kausal, perijinan), B (perijinan, arbitrer, kausal), dan C (kausal, perijinan, arbitrer).

Rancangan sama-subjek dapat dilakukan secara faktorial, yaitu melibatkan lebih dari satu variabel independen. Misalnya, penelitian fiktif mengenai pengaruh jenis kemasan shampo dan volume terhadap minat membeli diteliti. Jenis kemasan shampo dibedakan kedalam tiga level, menjadi kemasan botol kaca, kemasan botol plastik dan kemasan sachet serta volume shampo yang dibedakan kedalam dua level, yakni $50 \mathrm{ml}$ dan $100 \mathrm{ml}$. Subjek penelitian adalah 40 mahasiswa psikologi Universitas $A B C$ dan setiap mahasiswa mendapatkan ketiga jenis kemasan serta dua volume tadi. Rancangan ini melibatkan 6 kombinasi iklan shampo: (1) Subjek melihat iklan shampo kemasan botol dengan volume $50 \mathrm{ml}$, lalu diminta mengisi skala minat membeli shampo; 2) Subjek melihat iklan shampo kemasan plastik dengan kemasan $50 \mathrm{ml}$ dan diminta mengisi skala minat membeli; 3) Subjek melihat iklan shampo kemasan sachet dengan volume $50 \mathrm{ml}$ dan diminta mengisi skala minat membeli; 4) Subjek melihat iklan shampo kemasan botol dengan volume $100 \mathrm{ml}$, lalu diminta mengisi skala minat membeli shampo; 2) Subjek melihat iklan shampo kemasan plastik dengan kemasan $100 \mathrm{ml}$ dan diminta mengisi skala 
minat membeli; 3) Subjek melihat iklan shampo kemasan sachet dengan volume $100 \mathrm{ml}$ dan diminta mengisi skala minat membeli. Dalam penelitian ini ada dua faktor, yaitu faktor pertama (A) mempunyai tiga level (a1, $a_{2}$, dan a3) dan faktor kedua (B) mempunyai 2 level ( $b_{1}$ dan $b_{2}$ ) sehingga ada rancangan $3 \times 2$ faktorial sama-subjek. Setiap subjek akan mendapatkan 3 × $2=6$ kondisi perlakuan yang berbeda. Setiap subjek akan melihat iklan shampo dalam 3 jenis kemasan yang isinya baik $50 \mathrm{ml}$ dan $100 \mathrm{ml}$.

Rancangan faktorial sama-subjek (3×2) dapat digambarkan sebagai berikut:

$\mathrm{R} \mathrm{Xa}_{1} b_{1} \mathrm{O}_{1} \mathrm{Xa}_{1} b_{2} \mathrm{O}_{2} \mathrm{Xa}_{2} \mathrm{~b}_{1} \mathrm{O}_{3} \mathrm{Xa}_{2} \mathrm{~b}_{2} \mathrm{O}_{4} \mathrm{Xa}_{3} \mathrm{~b}_{1} \mathrm{O}_{5} \mathrm{Xa}_{3} \mathrm{~b}_{2} \mathrm{O}_{6}$

Gambar 14. Rancangan faktorial sama-subjek

Rancangan faktorial sama subjek juga perlu di counterbalancing sehingga gambar 14 dapat menjadi beberapa variasi kombinasi kondisi perlakuan, misalnya dengan partial counterbalancing yang memilih tiga kombinasi secara acak dari kemungkinan kombinasi urutan kondisi perlakuan kepada 40 subjek dapat menjadi (lihat Gambar 15).

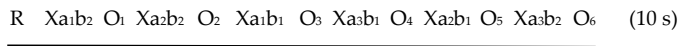

$$
\begin{aligned}
& \begin{array}{lllllllllllllllll}
\mathrm{R} & \mathrm{Xa}_{2} b_{2} & \mathrm{O}_{1} & \mathrm{Xa}_{3} \mathrm{~b}_{1} & \mathrm{O}_{2} & \mathrm{Xa}_{1} b_{2} & \mathrm{O}_{3} & \mathrm{Xa}_{3} b_{2} & \mathrm{O}_{4} & \mathrm{Xa}_{2} b_{1} & \mathrm{O}_{5} & \mathrm{Xa}_{1} b_{1} & \mathrm{O}_{6} & (10 \mathrm{~s})
\end{array}
\end{aligned}
$$

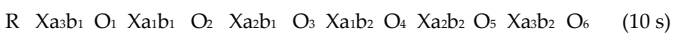

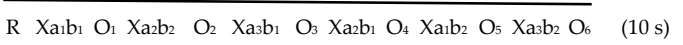

Gambar 15. Rancangan samasubyek faktorial yang di partial counterbalancing

\section{Rancangan Campuran (Mixed Designs)}

Myers dan Hansen (2001) merumuskan rancangan campuran mengkombinasikan satu faktor yang dimanipulasi dalam rancangan sama-subjek dengan faktor lain yang berbentuk rancangan beda-subjek. Misalnya, sebuah eksperimen meneliti pengaruh tingkatan suhu ruang kerja dan kebisingan ruang kerja perakit sepeda motor terhadap produktivitas kerja. Tingkatan suhu ruangan (Faktor A) dimunculkan $10^{\circ} \mathrm{C}$ (a1) dan $25^{\circ} \mathrm{C}$ (a2), sementara itu kebisingan kerja (Faktor B) dibuat variasi $10 \mathrm{db}\left(\mathrm{b}_{1}\right), 30 \mathrm{db}\left(\mathrm{b}_{2}\right)$, dan $60 \mathrm{db}\left(\mathrm{b}_{3}\right)$. Untuk variabel tingkatan suhu dilakukan rancangan beda-subjek, jadi subjek yang mendapatkan $10^{\circ} \mathrm{C}$ (a1) berbeda dengan subjek yang mendapatkan $25^{\circ} \mathrm{C} \quad\left(\mathrm{a}_{2}\right)$. Sedangkan untuk variabel kebisingan dilakukan dengan rancangan sama-subjek, jadi subjek yang mendapatkan $10 \mathrm{db}\left(\mathrm{b}_{1}\right)$, $30 \mathrm{db}\left(\mathrm{b}_{2}\right)$, dan $60 \mathrm{db}\left(\mathrm{b}_{3}\right)$ adalah sama orangnya. Gambaran eksperimen tergambar dalam Tabel 1.

Rancangan Tabel 1 dapat digambarkan sebagai berikut:

$$
\begin{aligned}
& \mathrm{R} X \mathrm{a}_{1} \mathrm{~b}_{1} \mathrm{O}_{1} \mathrm{Xa}_{1} \mathrm{~b}_{2} \mathrm{O}_{2} \mathrm{Xa}_{1} \mathrm{~b}_{3} \mathrm{O}_{3} \\
& \mathrm{R} \mathrm{Xa}_{2} \mathrm{~b}_{1} \mathrm{O}_{1} \mathrm{Xa}_{2} \mathrm{~b}_{2} \mathrm{O}_{2} \mathrm{Xa}_{2} \mathrm{~b}_{3} \mathrm{O}_{3}
\end{aligned}
$$

Gambar 16. Rancangan campuran

Dalam rancangan campuran, maka hanya faktor sama subjek (within-subject) saja yang dicounterbalanced (Myers \& Hansen, 2002, hlm. 288) sehingga dalam eksperimen diatas maka hanya faktor kebisingan saja (10 db, $20 \mathrm{db}$ dan $60 \mathrm{db}$ ) atau faktor $B\left(b_{1}, b_{2}\right.$ dan $\left.b_{3}\right)$ yang di counterbalanced. Ada duabelas kemungkinan kombinasi yang mungkin terjadi maka jika dengan partial counterbalanced terpilih enam kombinasi secara acak, gambar rancangan akan sebagai berikut (gambar 17) untuk delapan orang setiap kombinasi kondisi perlakuan. 
Tabel 1

Gambaran eksperimen

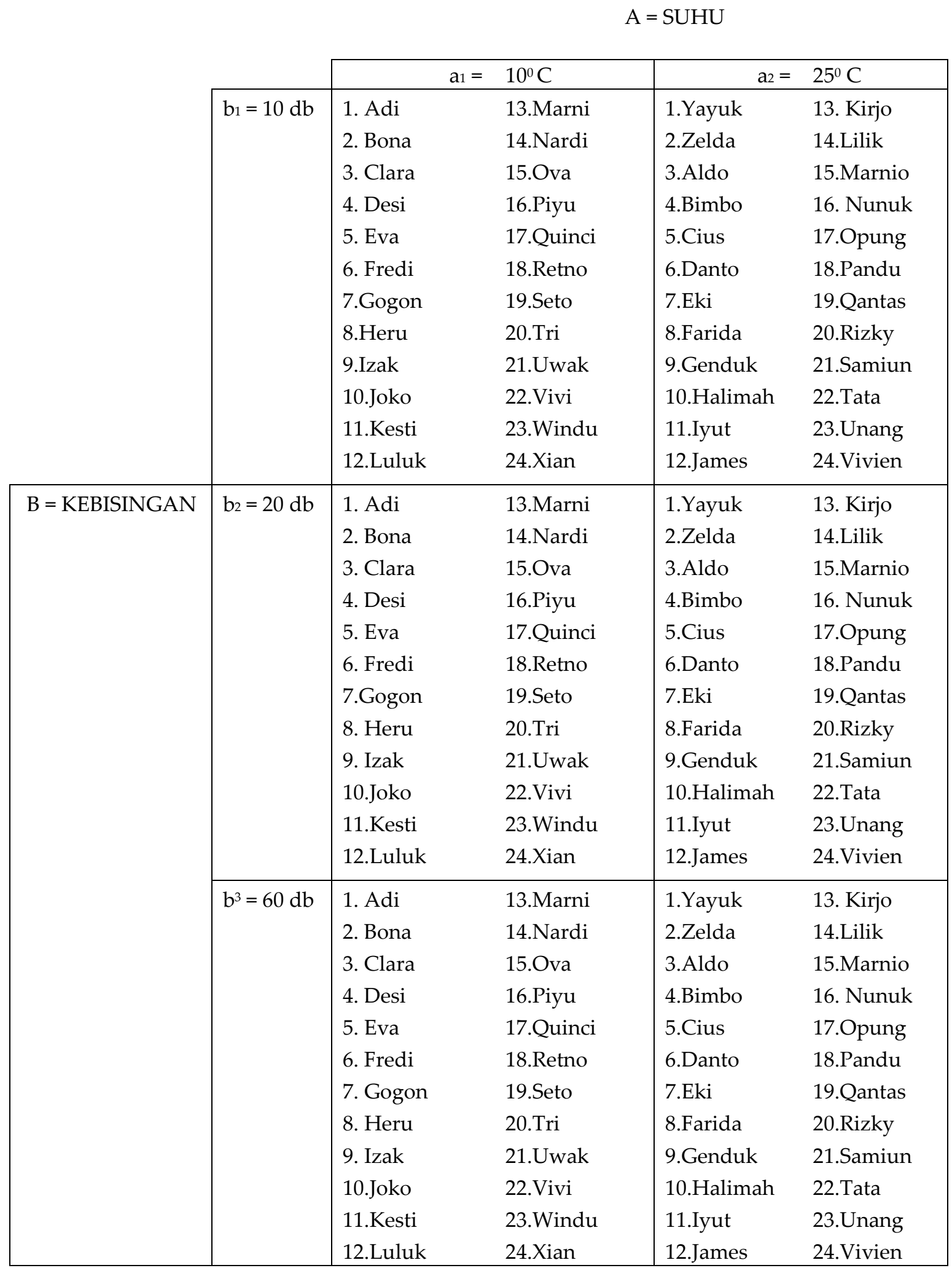




\begin{tabular}{|c|c|c|c|c|c|}
\hline $\mathrm{R}$ & $X_{a_{1} b_{1}} O_{1} \quad X_{1} b_{2}$ & $\mathrm{O}_{2}$ & $\mathrm{Xa}_{1} \mathrm{~b}_{3}$ & $\mathrm{O}_{3}$ & (untuk 8 orang) \\
\hline & $X_{1} b_{2} \quad O_{1} \quad X_{1} b_{1}$ & $\mathrm{O}_{2}$ & $\mathrm{Xa}_{1} \mathrm{~b}_{3}$ & $\mathrm{O}_{3}$ & (untuk 8 orang) \\
\hline & $\mathrm{Xa}_{1} b_{3} \quad \mathrm{O}_{1} \mathrm{Xa}_{1} \mathrm{~b}_{2}$ & $\mathrm{O}_{2}$ & $\mathrm{Xa}_{1} \mathrm{~b}_{1}$ & $\mathrm{O}_{3}$ & (untuk 8 orang) \\
\hline $\mathrm{r}$ & $\begin{array}{lll}X_{2} b_{1} & O_{1} & X_{2} b_{2}\end{array}$ & $\mathrm{O}_{2}$ & $\mathrm{Xa}_{2} \mathrm{~b}_{3}$ & $\mathrm{O}_{3}$ & (untuk 8 orang) \\
\hline 1 & $\mathrm{Xa}_{2} \mathrm{~b}_{2} \mathrm{O}_{1} \mathrm{X}_{2} \mathrm{~b}_{3}$ & $\mathrm{O}_{2}$ & $\mathrm{Xa}_{2} \mathrm{~b}_{1}$ & $\mathrm{O}_{3}$ & (untuk 8 orang) \\
\hline & ${ }_{3} \quad \mathrm{O}_{1} \quad \mathrm{Xa}$ & 12 & $\mathrm{X}_{2} \mathrm{~b}_{2}$ & $\mathrm{O}_{3}$ & (untuk 8 orang) \\
\hline
\end{tabular}

Gambar 17. Rancangan campuran tercounterbalanced

Soal berapa banyak subjek dalam setiap kondisi perlakuan, silakan mengkaji penelitian terdahulu sebagai panduan. Sebagai patokan umum, disarankan sekurang-kurangnya ada 15 atau 20 subjek disetiap kelompok (Myers \& Hansen, 2002, h.217).

\section{Penutup}

Rancangan eksperimen adalah struktur umum sebuah eksperimen yang ditentukan oleh tiga aspek (a) jumlah variabel independen atau perlakuan, (b) jumlah variasi variabel independen atau kondisi perlakuan, dan (c) penggunaan subjek yang sama atau berbeda untuk masingmasing kondisi perlakuan. Tidak semua buku metode eksperimen menuliskan notasi rancangan eksperimen acak. Penulis mengusulkan notasi eksperimen acak untuk keperluan pedagogis dengan mencampurkan notasi Kirk (1982) dan Shadish, Cook \& Campbell (2002) dengan modifikasi.

\section{Daftar Pustaka}

Affandi, G. R., \& Hastjarjo, T. D. (2010). Pengaruh Tipe penentuan Tujuan (Goal-setting) Terhadap Performansi Akademik bahasa Inggris Siswa dengan Efikasi Diri dan Kemampuan Awal Bahasa Inggris Sebagai Kovariabel. Jurnal Psikologi Tabularasa, 5(2),
264-368.

Alsa, A. (2007). Metode Kuantitatif $\mathcal{E}$ Kualitatif Serta Kombinasinya dalam Penelitian Psikologi. Pustaka Pelajar: Yogyakarta.

Azwar, S. (1998). Metode Penelitian. Pustaka Pelajar: Yogyakarta.

Barlow, D. H., \& Hersen, M. (1984). Singlecase Experimental Designs: Strategies for Studying Behavior Change. $2^{\text {nd }}$ Edition. Pergamon Press: New York.

Campbell, D. T., \& Stanley, J. C. (1966). Experimental and Quasi-Experimental Designs for Research. Rand McNally \& Co: Chicago.

Cook, T. D., \& Campbell, D. T. (1979). Quasi-Experimentation: Design \& Analysis Issues for Field Settings. Houghton Mifflin Co: Boston.

Cooper J. O, Heron T.E , \& Heward W. L. (1987). Applied behavior analysis. Macmillan: New York.

Creswell. J. W. (2009). Research Design: Qualitative, Quantitative and Mixed Methods Approaches. Sage Publication Inc: Thousand Oaks, CA.

D'Amato, M. R. (1970). Experimental Psychology: Methodology, Psychophysics, $\mathcal{E}$ Learning. McGraw Hill Text: New York.

Etsem, M. B., Walgito, B., Sugiyanto., \& Priyosulitiyo. (2008). Sarana Navigasi Kognitif sebagai Upaya Peningkatan 
Kemudahan Evakuasi pada Bangunan Mal/Fasilitas-Umum. Jurnal Psikologi, 35(1), 41-61.

Faesal. (1997). Pengaruh Jenis Kertas brosur A, B, C terhadap Persepsi Kualitas Komputer. (Skripsi tidak diterbitkan). Fakultas Psikologi UGM: Yogyakarta.

Gazzaniga, M., Heatherton, T., \& Halpern,

D. (2011). Psychological Science, $4^{\text {th }}$

Ed. W.W. Norton \& Company: New York. NY.

Goodwin, C. J. (2010). Research in Psychology: Methods and Design. $6^{\text {th }}$ Edition. John Willey \& Sons, Inc: Hoboken, NJ.

Hastjarjo, T. D. (2004). Penalaran Deduktif Mahasiswa. Anima, 20(1), 3-11.

Hastjarjo, T. D. (2010). Eksperimen-kuasi dan Generalisasi Inferensi Kausal. Proceedings Konferensi Nasional Eksperimen di Fakultas Psikologi UGM: Yogyakarta, Januari 2010.

Hastjarjo, T. D (2011). Kausalitas Menurut Tradisi Donald Campbell. Buletin Psikologi, 29(1), 1-X

Hergenhahn, B. R., \& Olson, Matthew. H. 2001. An Introduction to Theories of Learning. Prentice-Hall, Inc., New Jersey.

Kazdin, A. (1982). Single-case Research Design: Methods for Clinical and Applied Settings. Oxford University Press: New York.

Keppel, G., \& Wickens, T.D. (2004). Design and Analysis: A Researcher's Handbook. $4^{\text {th }}$ Edition. Pearson Prentice Hall: Upper Saddle River, New Jersey.

Kerlinger, F. N. (1986). Foundations of Behavioral Research. 3 ${ }^{\text {rd }}$ Edition. Holt, Rinehart and Winston: New York.

Kerlinger, F. N., \& Lee, H. B. (2000). Foundations of Behavioral Research. $4^{\text {th }}$ Edition. Harcourt College Publisher: Fort Worth.
Kirk, R. E. (1982). Experimental Design: Procedure for the Behavioral Science. $2^{\text {rd }}$ Edition. Brooks/Cole Publishing Company: Monterey, California.

McGuigan, F. J. (1987). Experimental Psychology. $7^{\text {th }}$ Edition. Simon \& Schuster (Asia) Pte Ltd: Singapore.

Myers, A., \& Hansen, C. H. (2002). Experimental Psychology. Wadsworth: Pacific Grove, CA.

Nadira. (2010). Pengaruh Kekonkritan Kata Terhadap Performansi Memori Jangka Pendek dengan Mempertimbangkan Tingkat Efikasi Diri Memori Mahasiswa. (Skripsi tidak dipublikasikan). Fakultas Psikologi, UGM: Yogyakarta.

Passer, M., \& Smith, R. (2007). Psychology: The Science of Mind and Behavior. McGraw Hill, New York.

Poerbosari. (1995). Perbedaan Efektivitas Cara Melatih Tari terhadap Keterampilan Menari. (Skripsi tidak dipublikasikan). Fakultas Psikologi UGM: Yogyakarta.

Sani, F., \& Todman, F. (2006). Experimental Design and Statistics for Psychology. Blackwell Publishing: Maden, CA

Shadish, W. R., Cook, T. D., \& Campbell, D. T. (2002). Experimental and QuasiExperimental Designs for Generalized Causal Inference. Houghton Mifflin Co: Boston.

Solso, R. L., Johnson. H. H., \& Beal, M. K. (1998). Experimental Psychology: A Case Approach. $6^{\text {th }}$ Edition. Longman: New York.

Townsend, J. C. (1953). Introduction to Experimental Method. McGraw Hill Book Company, Inc: New York.

Utomo, W. K. (2007). Pengaruh Emosi Positif terhadap Performansi Memori Jangka Pendek. (Skripsi tidak dipublikasikan). Fakultas Psikologi, UGM: Yogyakarta. 